\title{
Imaging features of catastrophic temporomandibular joint disorder in a case with new classification
}

\author{
Katastrofik temporomandibular eklem hastalığı, yeni sınıflama ile bir olguda \\ radyolojik özellikleri
}

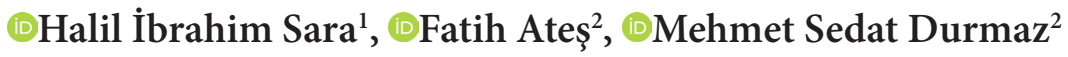 \\ ${ }^{1}$ University of Health Sciences, Dr. Abdurrahman Yurtaslan, Ankara Oncology Training and Research Hospital, Radiology Department, \\ Ankara, Turkey \\ ${ }^{2}$ Selcuk University, Medical Faculty, Radiology Department, Konya, Turkey
}

Cite this article as/Bu makaleye atıf için: Sara Hİ, Ateş F, Durmaz MS. Imaging features of catastrophic temporomandibular joint disorder in a case with new classification. J Health Sci Med 2020; 3(4): 496-498.

\begin{abstract}
Temporomandibular joint disorders (TMJD) have complex and diverse etiologies. Various classifications have been created in order to better describe and to guide the treatments correctly of these disorders. Wilkes classification is the most accepted among these classifications. A more comprehensive and understandable classification has been developed by Dimitroulis to eliminate the short comings of other classifications. In this case we aimed to present category 5 catastrophic temporomandibular joint disorders with radiological findings according to this new classification.
\end{abstract}

Keywords: Temporomandibular joint, radiology, MRI, CT

\section{ÖZ}

Temporomandibular eklem bozukluklarının (TMJD) karmaşık ve çeşitli etiyolojik sebepleri vardır. Bu bozuklukların daha iyi tanımlanması ve tedavilerinin doğru bir şekilde yönlendirilmesi için çeşitli sınıflandırmalar oluşturulmuştur. Wilkes sınıflandırması, bu sınıflandırmalar arasında en çok kabul gören sınıflamadır. Diğer sınıflandırmaların eksikliklerini ortadan kaldırmak için Dimitroulis tarafından daha kapsamlı ve anlaşılır bir sınıflandırma geliştirilmiştir. Bu vakada bu yeni sınıflandırmaya göre kategori 5 katastrofik temporomandibular eklem bozukluklarını radyolojik bulgularla sunmayı amaçladık.

Anahtar Kelimeler: Temporomandibular eklem hastaliği, radyoloji, MRG, BT

\section{INTRODUCTION}

Temporomandibular joint disorders (TMJD) have complex and sometimes controversial etiologies and treatment methods (1-3). TMJD were tried to be categorized by various classification methods (3-6). By making classifications, it is aimed to create appropriate and standard treatment methods that will be accepted worldwide at different stages or in situations with different etiologies (5-8). These classifications are also important for standardization in order to compare the clinical results of the treatments and surgical techniques applied (9). There are 3 main classifications related to TMJD; the Research Diagnostic Criteria (RDC) for TMJD, the Wilkes Classification for TMJD internal derangement, and the American Academy of Orofacial Pain (AAOFP) Classification of TMJD (8-11). The Wilkes classification is the most widely used classification that has been adopted by surgeons who treat TMJD $(3,9)$. Its widespread adoption is linked to its simplicity in describing escalating joint pathology in 5 stages, but it concentrates on only 2 disorders (internal derangement and osteoarthritis) and fails to include other TMJD such as ankylosis and tumours (10). Therefore, in 2013, Dimitroulis developed 
a new surgical classification that includes all TMJ-specific disorders that can be applied to future studies on TMJ surgery. The main features and surgical treatment options of this classification are shown in Table (9).

In this article, we aimed to present the radiological findings of a case with category 5 catastrophic TMJD which we reported according to a new surgical classification and thus hoped to guide surgeons more accurately.

\begin{tabular}{|c|c|}
\hline Category 1 & $\begin{array}{l}\text { TMJ normal } \\
\text { No surgery required or indicated }\end{array}$ \\
\hline Category 2 & $\begin{array}{l}\text { TMJ minor changes (all joint components are } \\
\text { salvageable) } \\
\text { TMJ arthrocentesis/arthroscopic lavage }\end{array}$ \\
\hline Category 3 & $\begin{array}{l}\text { TMJ moderate changes (most joint components are } \\
\text { salvageable) } \\
\text { TMJ operative arthroscopy/TMJ arthroplasty }\end{array}$ \\
\hline Category 4 & $\begin{array}{l}\text { TMJ severe changes (few joint components are } \\
\text { salvageable) } \\
\text { TMJ discectomy } \pm \text { condylar surgery }\end{array}$ \\
\hline Category 5 & $\begin{array}{l}\text { TMJ catastrophic changes (nothing in the joint is } \\
\text { salvageable) } \\
\text { TMJ resection } \pm \text { total joint replacement }\end{array}$ \\
\hline
\end{tabular}

TMJ: Temporomandibular joint, TMJD: Temporomandibular joint disorders

\section{CASE}

A 46-year-old woman presented to the otolaryngology clinic with complaints of swelling, not being able to chew anything, locking and mild pain in left TMJ. On physical examination, swelling, malocclusion and crepitus were noticed at the localization of TMJ. Afterwards, Computer tomography (CT) and Magnetic Resonance Imaging (MRI) was performed and reporting was done by evaluating two investigations together.

Enlargement on the TMJ face of the left temporal bone, narrowing in the joint space, osteophytic tapering at the joint corners, sclerotic appearance and expansion were observed. A marked increase in left mandibular condyle width, cortical irregularity and sclerotic appearance were observed on the articular face. On the left, the joint disc could not be visualized and TMJ was ankylosed. In line with these findings, we reported category $5 \mathrm{TMJ}$ by catastrophic changes in the left TMJ (Figure).

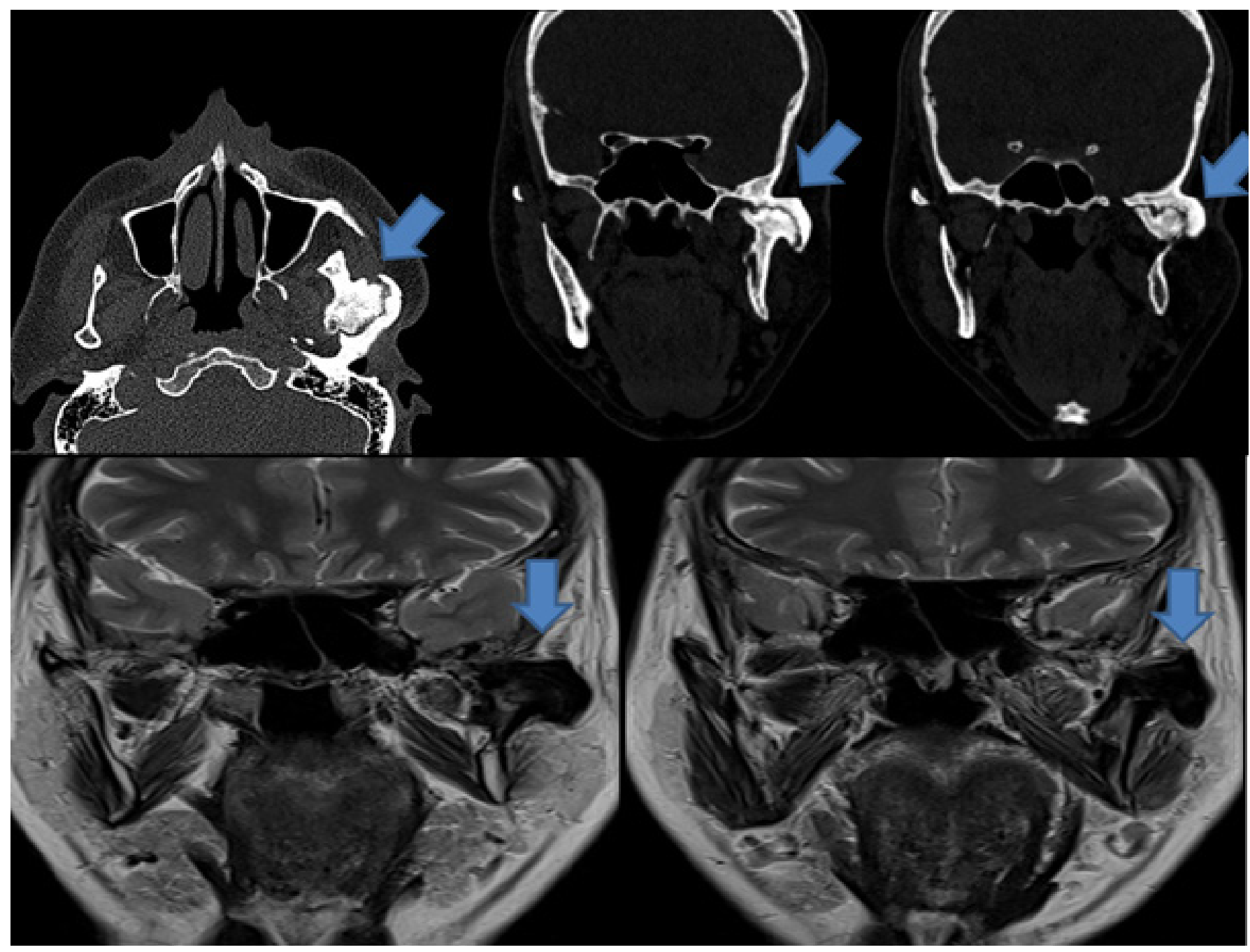

Figure. Ankylosis of the left temporomandibular joint, expansion of the joints, irregularities on the face of joint, new bone formation, sclerosis, and deformity in the bone structures involved were observed. 


\section{DISCUSSION}

There are several classification methods in which TMJD are categorized (8-11). Of these, the Wilkes classification has been used as the unofficial standard classification for TMJ surgeons worldwide for many years. The simplicity of the stages identified and the increase in the level of disease at each stage made this classification feasible $(3,10)$. However, considering that there are some deficiencies in the scope of these classifications, Dimitroulis developed a new surgical classification in 2013 that includes all TMJspecific disorders that can be applied to future studies on TMJ surgery. This classification developed by Dimitroulis addresses the TMJD more extensively, and the classification not only identifies the clinical and radiological features of each category, but also shows the degree of surgical intervention (9). As we thought it would enable us to establish a clear communication between radiologists and surgeons and to guide surgeons more accurately. In this way, we reported our case based on this classification and received positive feedback from surgeons. In this classification, TMJD are divided into 5 categories that increase in parallel with the severity of the disease.

According to this classification, the categories have the following characteristics radiologically;

Category 1: This category corresponds to the normal TMJ. Patients present with pain complaints, but physical examination and radiological imaging are normal.

Category 2: There are minor changes in the joint in this category. MRI may have mild disc displacement, an increase or decrease in joint fluid as an indicator of inflammation.

Category 3: Includes moderate changes. Non-reductive disc displacement is seen in MRI. Mild disc contour deformity and condyle dislocation or fracture can be seen. Longterm cases may be affected by synovial chondromatosis and TMJ internal derangement.

Category 4: Includes severe TMJ changes. CT scans may show radiological signs of early changes in condylar morphology, such as loss or thinning of cartilage layer and osteophyte, small subcondral cysts, condyle head straightening, and beak type deformities. MRI can show severely degenerated, displaced and deformed joint disc, and sometimes disc perforation.

Category 5: Catastrophic changes occur. Irregular joint surface and large subchondral cysts are seen on CT scans. Although it is difficult to visualize because of irregular and deformed condyle, highly degenerated disc can be seen on MRI. In cases where joint pain is absent or tolerable, the patient may experience TMJ osteoarthrosis, or in rare cases, TMJ ankylosis or tumor. Our case falls into this category in a way that leaves no doubt due to the advanced changes and ankylosis described in TMJ (9).

\section{CONCLUSION}

We recommend that this new classification which we have started to use in our reports, and which we think may be effective in forming a common language among the physicians in the description of the disease and guide the treatment correctly, should be kept in mind by radiologists whose evaluating TMJ.

\section{ETHICAL DECLARATIONS}

Informed Consent: Written informed consent was obtained from all participants who participated in this study.

Status of Peer-review: Externally peer-reviewed.

Conflict of Interest Statement: The authors have no conflicts of interest to declare.

Financial Disclosure: The authors declared that this study has received no financial support.

Author Contributions: All of the authors declare that they have all participated in the design, execution, and analysis of the paper, and that they have approved the final version.

\section{REFERENCES}

1. Kahn J, Tallents RH, Katzberg RW, Ross ME, Murphy WC. Prevalence of dental occlusal variables and intraarticular temporomandibular disorders: molar relationship, lateral guidance, and nonworking side contacts. J Prosthet Dent 1999; 82: 410-5.

2. Katzberg RW, Tallents RH. Normal and abnormal temporomandibular joint disc and posterior attachment as depicted by magnetic resonance imaging in symptomatic and asymptomatic subjects. J Oral Maxillofac Surg 2005; 63: 1155-61.

3. Murphy MK, MacBarb RF, Wong ME, Athanasiou KA. Temporomandibular disorders: a review of etiology, clinical management, and tissue engineering strategies. Int J Oral Maxillofac Implants 2013; 28: e393-e414.

4. Young AL. Internal derangements of the temporomandibular joint: A review of the anatomy, diagnosis, and management. J Indian Prosthodont Soc 2015; 15: 2-7.

5. Dimitroulis $\mathrm{G}$. The role of surgery in the management of disorders of the temporomandibular joint: a critical review of the literature. Part 2. Int J Oral Maxillofac Surg 2005; 34: 231-7.

6. Dimitroulis G. The role of surgery in the management of disorders of the Temporomandibular Joint: a critical review of the literature. Part 1. Int J Oral Maxillofac Surg 2005; 34: 107-13.

7. Dolwick MF, Dimitroulis G. Is there a role for temporomandibular joint surgery? Br J Oral Maxillofac Surg 1994; 32: 307-13.

8. Anderson GC, Gonzalez YM, Ohrbach R, Truelove EL, Sommers E, Look JO, et al. The Research Diagnostic Criteria for Temporomandibular Disorders. VI: future directions. J Orofac Pain 2010; 24: 79-88.

9. Dimitroulis G. A new surgical classification for temporomandibular joint disorders. Int J Oral Maxillofac Surg 2013; 42: 218-22.

10. Wilkes $\mathrm{CH}$. Internal derangements of the temporomandibular joint. Pathological variations. Arch Otolaryngol Head Neck Surg 1989; 115: 469-77.

11. Dworkin SF, LeResche L. Research diagnostic criteria for temporomandibular disorders: review, criteria, examinations and specifications, critique. J Craniomandib Disord 1992; 6: 301-55. 